AFTER SOCIAL HISTORY

Devon Orgeron, Marsha Orgeron, and Dan Streible, eds. Learning with the Lights Off: Educational Film in the United States

New York: Oxford University Press, 2012, 525 pp. ${ }^{1}$

\title{
Sol Cohen
}

"The word 'educational' is here used in a wide sense and does not indicate that these films are intended for school or college use exclusively. They are intended rather for the education of the adult as well as the youth, for the exhibition before miscellaneous audiences, as well as for more restricted use."

- George Kleine, Catalogue of Educational Motion Pictures

(NY: George Kleine, 1910), 1.

"[One must think] of education not only as formal pedagogy but as the entire process by which a culture transmits itself across the generations; [and] to see schools and universities fade into relative insignificance next to other social agencies."

— Bernard Bailyn, Education in the Forming of American Society:

Needs and Opportunities for Study (Durham, NC: University of North Carolina Press, 1960), 14.

"[There is a] need for a more inclusive account of our educational history. [The question that must be raised is] what agencies, formal and informal, have shaped American thought, character, and sensibility over the years, ... To ask 
the question thus is to project our concerns beyond the schools to a host of other institutions that educate."

- Lawrence A. Cremin, The Wonderful World of Ellwood Patterson

Cubberley: An Essay on the Historiography of American Education (NY:

Teachers College Press, 1965), 47-48.

To put it simply, Learning with the Lights Off: Educational Film in the United States (LWLO) is a path breaking and seminal exploration of a remarkable and remarkably understudied subject. I will go further to say that $L W L O$ is a major contribution to three academic disciplines: history of American cinema, American cultural history more generally, and history and historiography of American education.

Before I proceed, an omission, and an explanation, are necessary. LWLO focuses almost exclusively on education film in the United States. The history of educational film in Canada requires its own telling. ${ }^{2}$

Learning with the Lights Off is a monumental anthology; 22 chapters in all, almost 500 pages of text, oversized, liberally illustrated, including filmographies, and ranging across more than eight decades. The three co-editors are film studies scholars. Devin Orgeron and Marsha Orgeron teach film studies at North Carolina State University and are the co-editors of The Moving Image, the journal of the Association of Moving Image Archivists. Dan Streible teaches film studies at New York University and is the associate director of the university's Moving Image Archiving and Preservation Program. Streible is also the founder and director of the Orphan Film Project, which preserves, screens, and studies educational film.

LWLO opens with an Introduction by the editors followed by "A History of Learning with the Lights Off," a sweeping overview of the history of educational film by the editors covering the period from 1895 and the silent film era to 1980. This chapter is followed by a close historical study of the beginnings of educational film, "The Cinema of the Future: Visions of the Medium as Modern Educator, 1895-1910," by Oliver Gaycken. LWLO is bookended by a select guide to educational film collections in archives and libraries by Elena Rossi-Snook. In between, LWLO contains chapters written by each of the co-editors, as well as by film, media, or communications specialists like Miriam Posner, Lee Grieveson, Alison Griffiths, Jennifer Peterson, Kirsten Ostherr, Eric Schaefer, Anna McCarthy, and Victoria Cain, among others.

LWLO explores an extraordinarily eclectic and broad range of topics considered under the rubric of educational film and that functioned in a wide variety of non-school as well as school contexts. To give an idea of the sheer diversity of topics, an abbreviated description of the contents of some of the chapters follows, arranged roughly chronologically from 1895 to 1980: The National Association for the Study and Prevention of Tuberculosis and Red Cross Seal films; the Ford Motor Company, film, and education for "industrial citizenship"; the American Museum of Natural History, Eastman Kodak, and classroom nature films; the American College of Surgeons, film, and medical education; Bell Telephone, RCA, sound, and educational film; Western Electric, Electrical Research Products, Inc. (ERPI), film and modernizing American 
agriculture; the Rockefeller Foundation, the General Education Board, and experiments in educational film; the Alfred P. Sloan Foundation, the New York University Film Institute, and economics education; the Jam Handy Organization, film, and corporate and industrial promotion; the Museum of Modern Art and aesthetic education through film. LWLO concludes with a chapter dealing with sex and drugs educational films of the post-WWII period, and two chapters on race and intergroup relations educational films of the 1950s and 1960s.

Along with the organizations and institutions cited above, also active in the educational film realm were General Motors, Encyclopedia Britannica, McGraw-Hill, Yale University, the University of Chicago, the American Council on Education, the Moody Bible Institute, and the National Conference of Christians and Jews, among countless others. They are all in LWLO. Each essay in LWLO is grounded in a wealth of archival research. Footnotes point to an extensive and invaluable primary source literature in cinema and education journals. The detail in each essay is thick, but the essays are never dull. Now the challenge is how to do justice to LWLO as a major achievement in the history of American cinema while treating it as a seminal achievement in the history of American education, while coping with a monumental collection of essays, and given the inevitable constraints of space.

In their Introduction, the editors make the following argument: commercial, theatrical Hollywood feature films have dominated scholarly attention in the burgeoning discipline of film studies. However, they continue, there was this other cinema - nontheatrical, educational film — a realm of cinema that was ubiquitous in US public school classrooms and in American institutional and everyday life generally through most of the twentieth century. ${ }^{3}$ Yet, little scholarship in the burgeoning field of film studies was devoted to educational motion pictures. Film studies ignored this other cinema. Commercial, theatrical film dominated film studies. Educational film, for which Dan Streible has coined the evocative term, "orphan film," was overlooked, neglected or ignored by film studies scholars, or when noticed, dismissed as insignificant and ephemeral pieces of celluloid, of no scholarly value or cultural importance.

Lost by this oversight, the editors contend, were not only many of the educational films themselves, but "a sense of the significant role educational film played in America and world history, cinematic and otherwise." ${ }^{4}$ The editors' aim is to redress this oversight, bring to attention of cinema scholars this overlooked chapter of American cinema history, and restore educational film as a major field for activity in American cinema history. The editors of LWLO have accomplished all this and more. They have not only mounted a compelling case for a major re-assessment of the role of educational film in the history of American cinema, but they have also, albeit innocently, published a landmark and seminal work in the history and historiography of American education. First, LWLO's exploration of educational film opens a vast and uncharted territory for exploration in the history of American education. And second, LWOL shows the way for historians of American education to resume the cultural turn in the historiography of American education proposed by Bernard Bailyn and Lawrence Cremin in the early 1960s. 
This essay has its genesis in an invitation from American Journal of History to write a 600-word review of Learning with the Lights Off: Educational Film in the United States. My first thought, after glancing at the title, was that LWLO was just another exploration of Hollywood movies about American teens and high schools; just another study of American classroom education on screen as portrayed in commercial, mainstream Hollywood movies. I was way off base. If, as Umberto Eco says, good titles should muddle the mind, then Learning With the Lights Off: Educational Film in the United States is a great title. The sub-title, "Educational Film in the United States", is key. As defined by the editors, educational film is an umbrella term capacious enough to refer to any kind of nontheatrical motion picture whose explicit intent is "to teach, inform, instruct, or persuade" and that is exhibited in any kind of venue, within the classroom or outside of the classroom. ${ }^{5}$ The editors acknowledge that their definition of educational film follows that of pioneer film producer and distributor George Kleine's antecedent definition of educational film from his Catalogue of Educational Motion Pictures, published in 1910, arguably the founding text of the educational film movement in the US, and which I've supplied as an epigram above. ${ }^{6}$

LWLO divides educational motion pictures into two distinct sectors, but with porous boundaries. There are educational films produced specifically for exhibition in classrooms, and educational films produced specifically for exhibition in non-classroom venues. Classroom educational film dealt with every conceivable academic subject offered in the US public high school and upper grades curriculum. Educational film also taught manners, morals and social behavior: everything from lunchroom manners to driver safety to date etiquette to prevention of venereal disease; to alcohol and drug abuse warnings to contraception instruction to what to do in case of a nuclear emergency to the melioration of race prejudice.

Classroom films, however, were only one segment of a much larger realm of educational film sponsored, produced and distributed on behalf of business and industry, religious organizations, charities, sports clubs, the armed services, countless other governmental organizations, and more. These films were produced for screening in non-school venues like museums, libraries, church assembly halls, community and recreation centers, farmers' granges, the workplace, hospitals, prisons, ocean liners, department stores, and even commercial movie theaters in the silent film era; seemingly wherever people gathered.

The non-classroom educational film sector dealt with almost every subject imaginable. The public was instructed on everything from how to fight TB, to the wonders of the planetary system, to the "human side" of US Steel. Educational film taught the public to appreciate the art of Jackson Pollock and how to start and conduct group discussions about school and neighborhood integration. Educational film taught salesmen how to sell Ford automobiles and GM Chevys and Frigidaires, and to sell products door-to-door. Educational films taught farmers how to raise wheat crops, surgeons how to operate on the hand, salesgirls how to use a cash register, and soldiers how to use weapons and keep up morale on the home front during WWII. With no formal arrangement educational film was taken up simultaneously in the 
classroom and in innumerable and diverse extra-school locations, and with innumerable and diverse educational intentions. Both sectors are dealt with in LWLO.

The breadth of educational film production is bewildering; the number, variety and prominence of corporations, publishing houses, foundations, philanthropic organizations, universities, museums, and US government agencies sponsoring, producing, and distributing educational film, as well the extraordinary diversity of institutional settings that employed the medium of film, is a revelation. The sheer volume of educational film production is staggering. ${ }^{7}$ In 1926, A.P. Hollis' catalogue, Motion Pictures for Instruction, listed almost 1,500 educational films. In 1931, one study estimated that more than 35 companies were producing educational films and nearly 200 companies distributing them. The post-World War II era saw almost one thousand nontheatrical films produced each year. The 1948 Educational Film Guide alone listed almost 3,800 films. ${ }^{8}$ By the end of the World War II era, the nontheatrical educational film industry had become a parallel industry to the more celebrated entertainment film industry, and an alternative, parallel, informal educational system to the country's formal public educational system. ${ }^{9}$

After some time, it occurred to me that everything the editors of LWLO claimed about the ignorance or neglect of educational film by historians of American cinema and film studies scholars could, to my chagrin, be said of specialists in the history of American education; the existence of the educational film realm was also unbeknownst to historians of American education. Now I think it time to claim, or rather reclaim "Educational Film in the United States" for the history and historiography of American education. I say reclaim since $L W L O$ leads us directly to the cultural turn in the historiography of American education and to Bernard Bailyn and Lawrence Cremin both of whom, in the early 1960s, caught a glimpse of this vast and uncharted territory revealed by $L W L O$ under the rubric of educational film. The exploration of educational film by the editors and contributors to $L W L O$ is placed within the context of the historiography of American cinema. That Bailyn and Cremin and the historiography of American education are overlooked is not surprising; the editors and contributors to LWLO are cinema, media, and communications studies scholars not historians of American education. We need to turn the lens now, so to speak, to educational film in the context of the historiography of American education.

LWLO's expansive definition of "educational film" and its acknowledgement of, and engagement with, the countless agencies and institutions that have been involved in the education of the American people through educational film, makes it another significant marker for a cultural historiography of American education. Recall that LWLO's definition of educational film is an elaboration of George Kleine's antecedent definition of educational film dating from 1910. There is a line from Kleine to the editors of LWLO. And most readers of Historical Studies in Education will no doubt be a step ahead of me in placing Bailyn and Cremin's broad cultural definition of education in that line. To put it another way, to most readers of HSE, the broad, cultural definition of education advocated by Cremin and Bailyn in the early 1960s, as indicated by my epigrams, and exemplified in Cremin's iconic The Transformation of the School: Progressivism in American Education, 1876-1957(1961), and then further 
pursued by him in American Education: The Metropolitan Experience, 1876-1980 (1988), will have straightaway come to mind and they will recognize where I am heading. ${ }^{10}$ (I will refer mainly to Cremin from this point since Bailyn, after Education in the Forming of American Society, wrote next to nothing about the cultural turn in American educational historiography). With LWLO in hand, I undertook the task of rediscovering Cremin and the cultural turn in American educational historiography.

In the years following his shockingly premature death in 1990, the cultural revisionism Cremin advocated has found few followers. Whatever lasting success and prominence Cremin achieved with The Transformation of the School, his cultural turn does not now interest historians of American education very much. American Education: The Metropolitan Experience, 1876-1980, has not lasted well; Cremin's cultural historiographical work has almost disappeared from view. ${ }^{11}$ Or, some historians of American education may remember only his impossibly broad definition of education in The Metropolitan Experience. ${ }^{12}$ With the publication of LWLO, the time seems right to take a fresh look at Cremin's contributions to a cultural approach to American educational historiography.

LWLO establishes the continuing relevance and validity of several of Cremin's original cultural insights. Let's consider two things not often mentioned in connection with Cremin's work anymore. First, Cremin insisted that "education" in the history of American education was too narrowly conceived as formal schooling. That "education" had to be understood more inclusively as taking place beyond a formal school context. Youth and adults are educated by countless non-formal agencies and institutions and in innumerable and diverse venues outside the classroom. Second, in American Education: The Metropolitan Experience, Cremin was bold enough to tackle pop culture and the mass media of communication — books, magazines, newspapers, radio, TV, and motion pictures - as powerful instructors of the American people; indeed Cremin moves education, broadly conceived, to "the core of the American experience." 13 The publication of LWLO should help Cremin get the recognition he deserves for his contributions to a cultural historiography of American education.

In making the cultural turn, Cremin moved beyond thinking of education as simply taking place in schools and colleges to opening the discussion to every transmitter of culture and education, broadly conceived, in society. Now we come to a mystery and a puzzle. Cremin went far in meeting the challenge of popular culture and the mass media of communication as educators of the American people, but not far enough. Cremin missed a stop on the cultural turn, or aborted the turn too soon, or hit a blind spot on the turn and turned back too soon, I don't know how else to put it but metaphorically. Somehow, inexplicably, unaccountably, Cremin missed entirely the phenomenon of educational film both outside of and within the classroom context. This is not so much a criticism, as an observation, and a mystery and a puzzle.

In American Education: The Metropolitan Experience, Cremin does discuss motion pictures. By motion pictures, however, Cremin is referring only to commercial, mainstream Hollywood feature films. ${ }^{14}$ My point is not the totally anachronistic one that he should have known Learning With the Lights Off: Educational Film in the United States. My point is this: in American Education: The Metropolitan Experience, 
Cremin almost wholly dedicated the volume to a depiction of countless and diverse non-school agencies and institutions as educators of the American people: libraries, museums, churches, YMCA and YWCA, Boy and Girl Scouts, farmers' granges, Chautauqua circles, American Legion, sports clubs, and on and on. Cremin calls them "places of culture" and discusses them in Chapter 9 of American Education: The Metropolitan Experience. But, astonishingly, Cremin overlooked $16 \mathrm{~mm}$ blackand-white educational film, the medium virtually all these non-school agencies and institutions, these "places of culture" employed during a good part of the twentieth century to reach their intended audience. Astonishingly, since Cremin was the most learned historian of American education of his time and knew everything there was to know about the history of American education. Cremin had to have known about the educational film sector and then decided to overlook it. I cannot fathom why.

Equally astonishing, Cremin missed classroom educational film which, so to speak, was staring him in the face. I say staring him in the face, since during Cremin's tenure on the faculty at Teachers College, Columbia, TC was a leader in the classroom audiovisual movement of the 1950s and 1960s, a golden age for classroom educational film. There is no discussion of classroom educational film in American Education: The Metropolitan Experience. This too is a mystery and a puzzle I cannot explain.

In American Education: The Metropolitan Experience, Cremin and his army of research assistants somehow overlooked the realm of educational film in the history of American education. But they weren't the only ones. I have been teaching courses on Hollywood feature films and American secondary education on screen for several years and was vaguely aware of $16 \mathrm{~mm}$, black-and-white classroom and non-classroom educational films. I snubbed them as of no scholarly or cultural value. Now, I have to say, and perhaps some readers of Historical Studies in Education will say with me, in the words of Thomas G. Smith, 16 mm educational filmmaker, 1965-1980, "I didn't know about most of the things discussed in [Learning with the Lights Off] but I should have."15

Learning With the Lights Off is an introduction to educational film in the US for cinema historians and film studies specialists. This essay is an introduction to educational film in the United States for historians of American education. (For obvious reasons I would like to stop using the qualifier American, but I cannot). Cinema history and film studies can be intimidating for historians of education who are not specialists in the study of cinema. This is an attempt to make cinema more accessible to them while allowing me to share some first glimmers of understanding of the significance of educational film in American culture, in the American classroom, in American education history. It is a preliminary report from that vast and uncharted territory revealed in $L W L O .^{16}$

As the editors of $L W L O$ point out, countless millions of people in the US in the twentieth century have been instructed by way of educational film. Educational film proliferated beyond the confines of the commercial theater and the classroom to become deeply embedded in American everyday life. The nontheatrical educational film realm became a substantial counterpart or parallel realm to the commercial Hollywood film realm through much of the twentieth century. What can we 
learn from $L W L O$ about the role educational film played in American classrooms, in American education, broadly conceived, and in American culture?

We have a good idea of what was taught or better, screened, in classrooms through educational film but as to what "learning" took place, the answer is elusive, and the question is still to be explored in depth. There is anecdotal evidence and surmise, but in the end we simply do not know what students thought about educational film or learned from them; we know more about how teachers used classroom film, as we shall see. For now, what emerges from a close reading of LWLO is that classroom films were apparently of little consequence.

Marsha Orgeron observes of classroom films dealing with racial tensions in American cities in the late 1960s: "it is difficult to discern how these various films were received in the classroom by students or teachers who viewed them the time." ${ }^{17}$ About classroom films conveying lessons about sex and drugs in the $1940 \mathrm{~s}$ and 1950s, Eric Schaeffer concludes that these films could, if used to stimulate questions and discussion, provide teenagers with a modest amount of information when such information was hard to find. But Schaefer wonders how many teachers actually used film properly or "simply abdicated their responsibilities as educators to the clattering machine at the back of a darkened room."18 In her chapter on the American Museum of Natural History and educational film, Alison Griffiths observes that in the 1920s and 1930s generations of New York City schoolchildren saw AMNH delivery vans and motorcycles pulling up to their schools "bringing the magic of cinema into the classroom." But in later decades, cinema was "used during inclement weather to keep large numbers of children under control in the auditorium."19 Griffiths' lament seems a personal recollection of another time. There is a gap in film studies scholarship having to do with the collection of data about classroom educational film. For example, neither in LWLO nor in any of the literature dealing with classroom educational film with which I'm familiar, is there any reference to diaries, memoirs, or oral history. ${ }^{20}$

Why did educational motion pictures enjoy so little success in American schools? It is too easy for the editors to simply point readers to "Television, Video, Computers and the Death of Educational Films," the title of the concluding section of their chapter on the history of educational film in the US ${ }^{21}$ LWLO contains no comparative study of the influence of theatrical, Hollywood films versus nontheatrical classroom educational films on students. My guess is that researchers will find that, especially in the post-WWII era, classroom films which attempted to foster new modes of social behavior, manners, and morals among teenagers - how to walk, talk, dress, drive, and comport themselves at home or on a date - were thought "corny" by teenagers and could hardly compete with theater movie-going Friday and Saturday night, and life as portrayed in Hollywood feature motion pictures.

About one topic there is no need to guess. LWLO makes it clear that school teachers never accepted the visual medium: they saw nothing wondrous about motion pictures; Edison's newest invention, the state of the art visual technology, left them cold. The teacher's most commonly expressed public complaint about classroom films was that they promoted student laziness, student passivity, and were harmful to student's 
eyesight. ${ }^{22}$ The unsaid subtext was fear that motion pictures were a serious threat to their professional status. The more vocal advocates of film in the classroom became the more they fed into teacher worries for the future of their profession.

Teaching, at the turn of the twentieth century, at the very same time as the birth of the motion picture industry, was a newly professionalized field. Motion pictures aroused deep anxieties among teachers about "projectors taking over the classroom" and "machines" that would make them superfluous. The rank and file of teachers fought off classroom motion pictures. Their chief tactic was passive resistance: "they showed films, but didn't teach with them." ${ }^{23}$ At the top levels of the profession, however, there was wild enthusiasm. In 1934, US Commissioner of Education, George F. Zook, hailed classroom motion pictures as "a magical master teacher," a remark that lingers in the memory. ${ }^{24}$

What can we learn from $L W L O$ about that other educational film realm, non-classroom educational film? It is obvious that educational film enjoyed its greatest success in the non-school sector, for example in modernizing American agriculture, in promoting American business and industry, in medical education, and in the military during WWII. In her chapter, "Medical Education Through Film," Kirsten Ostherr argues that beginning in 1912 the American College of Surgeons placed motion pictures "at the center of surgical training" and thus established motion pictures as "fundamental to the practice of medicine." ${ }^{25}$ Educational film's success in the military during World War II is also established in LWLO. Cinema historian John Belton's comment about Hollywood feature films produced during WWII — that they were a "school for soldiers," is more applicable to $16 \mathrm{~mm}$ black-and-white nontheatrical military training and propaganda films produced during the war. Nontheatrical educational film not only helped train (and entertain) millions of soldiers but also did important work on the home front. The "Victory Loan" films produced by Hollywood for the US Treasury Department's annual war loan drives were enormously successful. ${ }^{26}$

The claims that are made in LWLO for the broader cultural significance of nontheatrical educational film are suitably vague and modest for this early stage of investigation. Educational films "tell us a great deal about the shape (and shaping) of the cinematic century (sic)." Educational film is a significant part of "the cultural fabric of the nation." Educational film "helped define the contours of the last and present centuries." ${ }^{27}$ And from the blurb on the back cover: "Educational films provide a catalog of twentieth century preoccupations and values. As a medium of instruction and guidance, they held a powerful cultural position, producing knowledge both inside and outside the classroom."

Missing in LWLO is some follow-up discussion of educational films as cultural phenomena intertwined with American public life, for example. Some obvious questions: what twentieth century "preoccupations and values" were educational films concerned with? granted the educational film sector occupied a "powerful cultural position" in the US, what "knowledge" did educational film produce?

A few contributors to $L W L O$ do venture into cultural history. Rick Prelinger concludes his chapter on the Jamison "Jam" Handy Organization with a quote from 
Bill Sandy, a long-time business associate of Handy's that has many layers of cultural meaning. Thanks to Handy's industrial and commercial promotional and sales films, many young people had the "mysteries of the business system ... stripped away and made hospitable." Handy "captured the romance of commerce" and showed how products like automobiles and appliances could be "mechanisms of liberation." 28 Another stab at the broader cultural significance of educational film is made in Katerina Loukopoulou's chapter on the Museum of Modern Art and educational film. In the post WWII period, Loukopoulou suggests, MoMA's films about Matisse, Willem de Kooning, and Jackson Pollock enabled viewers to better appreciate "the creative process of making art." MoMA employed educational film in "visually positioning the creative process in the public sphere of general education" thus creating a new audience for modern art. ${ }^{29}$

LWLO provokes thinking on a whole raft of questions about the wider cultural import of nontheatrical educational film. The following immediately come to mind: what was the role of educational film in the shift from nineteenth century Victorian values and sensibilities to modernism; in the assimilation of new immigrants into American urban society; in the incorporation of women into the workplace? What role did educational film play in newly emerging ideals of leisure, recreation, and consumption among the working class and middle class? And what about educational film as adult education? Did the circulation of educational film in diverse, countless and free non-formal school venues help urban immigrant and working class youth and adults; men and women, take possession of what Bourdieu calls " cultural capital" and thus foster social mobility? All await comprehensive historical study. ${ }^{30}$

Now some concluding observations are in order. In the historiography of American cinema, the landscape has already shifted and publications on educational film are proliferating. But exploration of educational film is still in its early days. Let's say thank you to our colleagues in cinema studies and reclaim educational film in the United States for the history and historiography of American education.

LWLO appears at an interesting moment in the US in the discipline of history of American education. Something is happening in the discipline that makes the publication of LWLO so timely, so right, so necessary. Social history of American education seems spent. One need look no further than the May 2013 issue of History of Education Quarterly, the main organ for the social history of American education in the US HEQ's May 2013. That number carries a stunning, doleful special theme issue: "If Life Were Endless, What Would You Study?" along with a melancholy, self deflating introduction, "Winding Down-Somewhat." 31 Reading the last rites of social history of American education into this number of $H E Q$ would be premature. "Winding Down?" More likely, social history is just taking a break. Or, if this issue of $H E Q$ heralds something more serious like the twilight of social history of American education, it does not herald the twilight of the history of American education. For historians of American education who are wondering about the history of American education after social history, the publication of LWLO presents an opportunity to continue the culture-centered approach to American educational history at the point where Cremin left it. The publication of $L W L O$ presents an opportunity for 
historians of American education to break from the more than four decade, near total hegemony of social history in the discipline. $L W L O$ is a wonderful spur to reflection on an entire century of history of American education. The "needs and opportunities" for historical study of educational film and American education seem inexhaustible. Whatever the topic, whatever the decade, whatever one is interested in, there is educational film. $L W L O$ points to a new direction in the history of American education that is endlessly suggestive of fruitful avenues of research and writing.

\section{Notes}

1 This essay had its genesis in an invitation to do a brief book review of Learning With the Lights Off (LWLO) from Journal of American History (JAH). This essay is a greatly revised and expanded version of the review. JAH, 100, 3 (Dec. 2013): 916-917.

2 A start is made by Charles R. Acland's discussion of the community film council movement in Canada in the 1940s and 1950s and the role of the National Film Society, the National Film Council, and the Canadian Broadcasting Company in promoting educational film. "Celluloid Classrooms and Everyday Projectionists: Post-World War II Consolidation of Community Film Activism," LWLO, Ch. 17, passim. Community or municipal and borough councils were also active in educational film in Great Britain. Elizabeth Leba, Forgotten Futures: British Municipal Cinema, 1920-1980 (London, UK: Black Dog Publishing, 2011). For a European flavor of educational film, see Vinzenz Hediger and Patrick Vonderau, Eds., Films that Work: Industrial Film and the Productivity of Media, (Amsterdam: University of Amsterdam Press, 2009).

3 As a practice, the classic form of educational film is the $16 \mathrm{~mm}$ ( $35 \mathrm{~mm}$ until 1923 , when Eastman Kodak introduced $16 \mathrm{~mm}$ stock) black-and-white film, with voice-over narration (silent until the early 1930s when $16 \mathrm{~mm}$ sound became the norm) and short; typical running time $8-15$ or 20 minutes. The term "nontheatrical" typically used to describe educational film does not imply not shown in commercial theaters; they were until about 1920 .

4 LWLO, 8.

5 Ibid.

6 Surprisingly, it was Edison's sometimes rival and business partner, the less well known film producer and distributor, George Kleine, who in the early years of cinema, was the key figure in the establishment of the educational film industry in the US. The early years at the birth of cinema were exciting, exhilarating, wondrous, but the motion picture industry was in chaos. The future shape of the industry was up for grabs. It wasn't clear where the future of motion pictures lay, in mass entertainment or in mass education. Kleine bet on educational films. The enormously popular nickelodeon theatres that swept the country beginning in 1905 required movies. Kleine saw a business opportunity in marketing educaitonal film for the nickelodeons. It was Kleine who first adopted the word "educational" as a term to describe scenic, industrials, actualities, Edison's ethnographic, public health, and social problem films, as well as Biblical tales and adaptations of literary classics. Kleine's 1910 Catalogue of Educational Motion Pictures was more than 300 pages in length and listed more than 1,000 "educational "films for sale or rent. Kleine promoted educational motion pictures for commercial exhibition not classroom exhibition. He envisaged the commercial movie theater as a kind of people's college; the "five cent university" was a familiar trope of the era, and predicted that educational film was destined to be the "cinema of the future." LWLO, 84-85. On the other hand Edison, also beginning in about 1910, promoted 
educational film for the public school classroom; a vast market, so he thought, for the sale or rent of camera and projection equipment, as well as film. Edison argued that visual images were easier for students to grasp than written words- "education through the eye" was another popular trope of the era — and envisaged a public school of the future with no books and few teachers. Edison's sensational proclamations about motion pictures replacing books almost made a still birth of the classroom educational film genre, and had to be repudiated by educational film advocates through the decades, LWLO, 68.

Neither Kleine nor Edison guessed right. Kleine was bankrupt by the early 1920s. There was no commercial theater market for educational film; by 1915 or so it was clear the future of the cinema industry lay as a mass entertainment medium. Edison never actually produced classroom educational films, and his dream of a made for classroom educational cinema began to be realized only in the late 1920s. In the meantime, the non-classroom educational film sector was kept afloat through a circuit of libraries, museums, churches, and community centers. Eileen Bowser, The Transformation of Cinema, 1907-1915 (Berkeley: University of California Press, 1994); Jennifer Lynn Peterson, Education in the School of Dreams: Travelogues and Early Nonfiction Film (Durham, NC: Duke University Press, 2013), 116ff; Haidee Wasson, Museum Movies: The Museum of Modern Art And the Birth of Art Cinema (Berkeley, CA: University of California Press, 2005).

7 The Ford Motor Company established a Sociology Department in 1914 and a Motion Picture Division within the Department and became the largest producer of educational films in the US in the silent era, especially in the years 1914-1921. Lee Grieveson, "Visualizing Industrial Citizenship," Ch. 4, LWLO, 108-109.

8 Ibid, 29, 47-48, 151.

9 The penetration of educational film into every nook and cranny of American society and culture would not have been possible without Eastman Kodak's introduction in 1923 of $16 \mathrm{~mm}$ film, and camera and projection equipment. Prior to 1923, the logistics made films practically prohibitive for widespread nontheatrical film exhibition generally and classroom film exhibition in particular. The staple $35 \mathrm{~mm}$ film gauge was expensive and highly flammable; the projection equipment bulky and heavy and required a special fireproof projection booth and a licensed operator to handle. Eastman Kodak's $16 \mathrm{~mm}$ film was nonflammable safety stock, and its camera and projection equipment were relatively inexpensive, lightweight, and portable. A special projection operator and fireproof projection booth were no longer required. Eastman Kodak's new motion picture technology (still silent, and black-and-white) revolutionized the educational film exhibition terrain. $16 \mathrm{~mm}$ film technology allowed educational motion pictures to become a mobile medium, and after 1923 educational film thrived in both school and non-school venues. Not the least of its ramifications, Eastman Kodak's introduction of $16 \mathrm{~mm}$ film enabled the appearance of "the female teacher as projectionist," Gregory A. Waller, "Projecting the Promise of 16 mm, 1935-1945," Charles. R. Acland and Haidee Wasson, eds., Useful Cinema, (Durham, NC: Duke University Press, 2011), 129, 146. Western Electric's subsequent introduction of sound on film projectors in 1934, "marked the final victory of $16 \mathrm{~mm}$ over $35 \mathrm{~mm}$ for nontheatrical use." LWLO, 46.

10 NY: Harpers \& Row, 1988. American Education: The Metropolitan Experience, 18761980 is the concluding volume of Cremin's three-volume cultural history of American education and the most relevant here.

11 Cremin is today almost forgotten. The recent volume of reminiscences by historians of American education is not a tribute to Cremin, as might be supposed by the book's cover portrait. Wayne J. Urban, ed., Leaders in the Historical Study of American Education (Rotterdam: Sense Publishers, 2011). 
12 "[Education is] the deliberate, systematic, and sustained effort to transmit, evoke, or acquire knowledge, values, attitudes, skills, and sensibilities, as well as any learning that results from that effort, direct, or indirect, intended or unintended," American Education: The Metropolitan Experience, $\mathrm{x}$.

13 Ibid., 12 and Ch. 7. "Media of Popular Communication," passim.

14 The chapter contains a light discussion of the beginnings of feature Hollywood motion pictures centering on D.W. Griffith and Edwin S. Porter, Ibid., 333-337.

15 Ibid., XIII.

16 I have suggested companion volumes to $L W L O$ here and there in my references.

17 LWLO, Ch. 19, “'A Decent and Orderly Society': Race Relations in Riot-Era Educational Films, 1966-1970," 439.

18 Ch. 14, "Exploitation as Education," 334. Schaefer's attention-catching title is not backed up in the chapter. See Robert Eberwein, Sex Ed (sic): Film, Video and the Framework of Desire (New Brunswick, NJ; Rutgers University Press, 1999), Ch.3.

19 LWLO, 143.

20 Research studies were conducted on the impact of using film in the classroom teaching of history, geography, and general science in 1924 and 1928, both funded by Eastman Kodak. The findings were mixed, but Eastman Kodak used the 1928 study in advertisements for its new subsidiary, Eastman Kodak Classroom Films, which dominated the classroom film sector in the late 1920s and early 1930s. LWLO, 3435, 122, 153-154. The better-known Payne Fund Studies of the early thirties were concerned only with the effect of commercial, Hollywood feature films on children and youth. Charles R. Acland, "Hollywood's Educators: Mark May and Teaching Film Custodians," Useful Cinema, passim.

21 LWLO, 61ff.

22 Ibid., 14, 36-37.

23 Ibid., 38-41. Acland indirectly addresses the issue of the teacher's attitude toward classroom film. He observes that Electrical Research Products Inc. (ERPI), the dominant producer and distributor of educational film in the mid-1930s and 1940s, was concerned that teachers were using its classroom films simply as "time filler." This concern led directly to ERPI's publication of numerous teaching manuals, study guides, and handbooks. Similar concerns expressed by Encyclopedia Britannica Films (EBF) in the post WWII era when it was the leading producer and distributor of educational films, and led to a proliferation of EBF teaching manuals, study guides, and handbooks. "Celluloid Classrooms and Everyday Projectionists." Ibid., 378-379.

24 Ibid., 146. Many of the questions raised in the US over the decades by educational film are raised again today in the era of MOOCs (Massive Open Online Courses). For example, from university administrators we hear that we are on the verge of a technological revolution; that MOOCs are the future of higher education and "standing still is not an option." From University faculty, we hear alarms about faculty becoming nothing more than "a glorified teaching assistant." Nathan Heller, "Annals of Higher Education: Laptop U,” New Yorker, 20 May 2013, 80, 88.

25 LWLO, 169.

26 The US Navy alone claimed to have produced about 1,000 films and to have distributed more than 10,000 films during the war. Waller, "Projecting the Promise of $16 \mathrm{~mm}, 1935-45$, "Useful Cinema, $135 \mathrm{ff}$.

27 LWLO, 5, 14, 66.

28 Ch. 15, "Smoothing the Contours of Didacticism: Jam Handy and His Organization," 353.

29 Ch. 16, "Museum At Large: Aesthetic Education Through Film," 372-374. 
30 There is a huge, easily accessible literature on Hollywood feature films and American culture. Although the nontheatrical educational film realm is never mentioned, the following books are useful in thinking about the place of educational film in American culture: Lary May, Screening Out the Past: The Birth of Mass Culture and the Motion Picture Industry (Chicago, Ill: University of Chicago Press, 1983); William Uricchio and Roberta E. Pearson, Reframing Culture: The Case of the Vitograph Quality Films (Princeton, NJ: Princeton University Press, 1993); and Miriam Hansen, Babel \& Babylon: Spectatorship in American Silent Film (Cambridge, MA: Harvard University Press, 1991).

31 53: 2, May 2013. 